\title{
Density, distribution, and activity of the ocelot Leopardus pardalis (Carnivora: Felidae) in Southeast Mexican rainforests
}

\section{Gabriela Pérez-Irineo* \& Antonio Santos-Moreno}

Laboratorio de Ecología Animal, Centro Interdisciplinario de Investigación para el Desarrollo Integral Regional, Unidad Oaxaca, Instituto Politécnico Nacional (IPN), Hornos 1003, Santa Cruz Xoxocotlán, Oaxaca 71230, México; gabyirineo@yahoo.com.mx, asantosm90@hotmail.com

* Correspondence

\author{
Received 30-IX-2013. Corrected 17-VI-2014. Accepted 21-VII-2014.
}

\begin{abstract}
The ocelot Leopardus pardalis is of particular significance in terrestrial communities due to its ecological role within the group of small-sized felids and as a mesopredator. However, despite the reduction of ocelot habitat in Southeast Mexico, there are still very few ecological studies. This research aimed to contribute with some ecological aspects of the species in this region. For this, 29 camera trap stations were established in a rain forest in Los Chimalapas (an area of $22 \mathrm{~km}^{2}$ ) during a two years period (March 2011-June, 2013), in Oaxaca state, Southeast Mexico. Data allowed the estimation of the population density, activity pattern, sex ratio, residence time, and spatial distribution. Population density was calculated using Capture-Recapture Models for demographically open populations; besides, circular techniques were used to determine if nocturnal and diurnal activity varied significantly over the seasons, and Multiple Discriminant Analysis was used to determine which of the selected environmental variables best explained ocelot abundance in the region. A total of 103 ocelot records were obtained, with a total sampling effort of 8529 trap-days. Density of $22-38$ individuals $/ 100 \mathrm{~km}^{2}$ was estimated. Ocelot population had a high proportion of transient individuals in the zone (55\%), and the sex ratio was statistically equal to $1: 1$. Ocelot activity was more frequent at night (1:00-6:00h), but it also exhibited diurnal activity throughout the study period. Ocelot spatial distribution was positively affected by the proximity to the village as well as by the amount of prey. The ocelot population here appears to be stable, with a density similar to other regions in Central and South America, which could be attributed to the diversity of prey species and a low degree of disturbance in Los Chimalapas. Rev. Biol. Trop. 62 (4): 1421-1432. Epub 2014 December 01.
\end{abstract}

Key words: camera-trapping, capture-recapture, Los Chimalapas, CJS Model.

Ocelot Leopardus pardalis (Linnaeus, 1758) distribution ranges from the Southern United States to Northern Argentina (Murray \& Gardner, 1997; Sunquist \& Sunquist, 2002). It is found in a wide variety of habitats where it coexists with other cats such as the jaguar Panthera onca (Linnaeus, 1758), the puma Puma concolor (Linnaeus, 1771), the margay Leopardus wiedii (Schinz, 1821), and the jaguarundi Puma yagouaroundi (Lacépède, 1809) (Murray \& Gardner, 1997; Sunquist \& Sunquist, 2002; de Oliveira et al., 2010). Within these habitats, the ocelot can impact other species due to its role as a mesopredator or through intraguild predation (Sunquist \& Sunquist, 2002; de Oliveira et al., 2010). In areas where other large-size predators are absent, such as the jaguar and the puma, this species may become the primary predator.

Some studies indicate that ocelots prefer areas with closed canopy and avoid large open areas (López-González, Brown, \& GalloReynoso, 2003; Harveson, Tewes, Anderson, \& Laak, 2004; Martínez-Calderas et al., 2011). The ocelot is mainly nocturnal, but in some areas exhibits day time activities (Ludlow \& Sunquist, 1987; Caso, 1994). The birth rate is $1: 1$, the subadults occupy the natal area until 
sexual maturity is reached, and take several months to occupy the permanent area as adults (Laak, 1991; Caso, 1994; Haines, Tewes, Laack, Grant, \& Young, 2005). Diet varies throughout its distribution: prey $<100 \mathrm{~g}$ are more frequent, however medium-sized prey provide greater biomass (de Oliveira et al., 2010).

Ocelot population density varies considerably across its distribution (de Oliveira et al., 2010) and presents a significant relationship with latitude and precipitation. This relationship has enabled the generation of a density model (Di Bitetti, Paviolo, De Angelo, \& Di Blanco, 2008a). Ocelot density has been calculated using radio telemetry data (Dillon \& Kelly, 2008) and camera trapping (Maffei, Noss, Cuéllar, \& Rumiz, 2005; Di Bitetti et al., 2008a). In camera trapping studies, estimates were made using capture-recapture data and demographically closed population models (Trolle \& Kéry, 2003; 2005; Kolowski \& Alonso, 2010; Díaz-Pulido \& Payan, 2011; González-Maya \& Cardenal-Porras, 2011). Nonetheless, demographically open population models are the most appropriate for long term research ( $>3$ months) as these models allow for individual entry and exit to the population of interest over time by birth, death, immigration and emigration (Lebreton, Burnham, Clobert, \& Anderson, 1992). Although this approximation has been employed in studies of felid populations (Gutiérrez-González, GómezRamírez, \& López-González, 2012), it has not yet been applied to ocelots.

Ocelot studies have been conducted in the Southern United States and in Central and South America. In Mexico, studies have been carried out in the Northern, Western, and central parts of the country in several habitat types, including dry tropical forest, submontane thornscrub, xeric shrublands and deciduous forest. Studies of Carnivora species in Southeast Mexico are few (Ceballos, Chávez, List, \& Zarza, 2007; Torres, 2009), even though this region has a high concentration of biodiversity in Carnivora (Valenzuela \& Vázquez, 2007). Moreover, this region is also covered by rainforest, which is one of the most vulnerable habitats (Reyes, Mas, \& Velázquez, 2010).

The region of Los Chimalapas is located in the Selva Zoque, Southeast Mexico, and it is one of the largest rainforest tracts in Mesoamerica (Salas, Schibli, \& Torres, 2001). It stands out for having more than 300000 ha of semideciduous tropical forest and tropical rain forest and more than $40 \%$ of Mexico's vertebrates, nine $(22 \%)$ of which are endemic to Mexico (Salas et al., 2001; Lira-Torres, Galindo-Leal, $\&$ Briones-Salas, 2012). Although the deforestation rate is low in Los Chimalapas, constant change in the forest cover is increasing, mainly in areas near water bodies and villages, but it is unknown if these areas are used by the species. Additionally, constant alterations can generate changes at the community or population levels. Given these modifications, it is convenient to conduct studies on the abundance of species in these environments and their trends over time. Ocelots are particularly important due to their ecological role within the felid assemblage as a mesopredator, however their population status and spatial distribution in this region are unknown. This ocelot ecology study aims to contribute with information on population density, activity patterns, sex ratio, residence, and spatial distribution in Los Chimalapas.

\section{MATERIALS AND METHODS}

Study Site: San Antonio Nuevo Paraíso is located in the Northern part of Los Chimalapas $\left(17^{\circ} 09^{\prime} 42^{\prime \prime} \mathrm{N}-94^{\circ} 21^{\prime} 20^{\prime \prime} \mathrm{W}\right)$, in the municipality of Santa María Chimalapa. Its vegetation includes tropical rain forest and chaparral. The regional climate is hot and humid, with annual temperatures ranging from 22 to $26^{\circ} \mathrm{C}$, and an annual precipitation of 2000 to $2500 \mathrm{~mm}$ (Trejo, 2004). The wet season lasts from June to December and the dry season from January to May. San Antonio Nuevo Paraíso has 140 inhabitants with cornfield and livestock areas.

Data collection: From March 2011 to June 2013, 29 sampling stations were installed, 22 of them equipped with one camera trap, and seven 
with two cameras operating independently. Traps were located on both sides of the trail in order to obtain images of both flanks of the animals so as to recognize them in subsequent shots (Trolle \& Kéry, 2003; Di Bitetti, Paviolo, \& De Angelo, 2006). Un-baited traps were placed at a height of $30 \mathrm{~cm}$ above ground, in the rainforest adjacent to rivers (three traps), inside the forest (14), on trails (four), and in areas adjacent to livestock (five). Because of the particular topographic conditions of Los Chimalapas, and as the minimum home range of a male $\left(3.5 \mathrm{~km}^{2}\right)$ includes two or three females (Sunquist \& Sunquist, 2002), traps were spaced from 0.5 to $1.5 \mathrm{~km}$ apart. The initial model was Wildgame IR4 4MP Digital Game Scouting Camera, and traps that failed were replaced by a ScoutGuard SG550/SG550V 5MP and a Bushnell Trophy Cam 5MP; 100\% of the initial traps were replaced during the study. All traps were programmed to stay active $24 \mathrm{~h}$. The delay period between photographs was set to $1 \mathrm{~min}$.

A preliminary filter was applied to avoid data duplication (Di Bitetti et al., 2006; Monroy-Vilchis, Zarco-González, Rodríguez-Soto, Soria-Díaz, \& Urios, 2011). For abundance calculations, all photographs taken by a trapping station during a $24 \mathrm{~h}$ period constituted a single independent record. Individual identifications were made according to spot patterns (Trolle \& Kéry, 2003). Due to a lack of photos of both flanks for each individual, analysis was based on the flank with the greater number of records. A capture-recapture history was built for each identified ocelot: their presence was established monthly and each month was considered a sampling occasion. Ocelot abundance was obtained using the Cormack-Jolly-Seber (CJS) open population model. Closed-population assumptions were evaluated with CloseTest (Stanley \& Richards, 1999) and the CJS model assumptions with U-CARE (Choquet, Lebreton, Gimenez, Reboulet, \& Pradel, 2009).

The CJS model assumes that each capture is an independent event, that capture and survival probabilities at a single capture occasion are the same for all animals, that capture and survival probabilities are equal across time intervals, and that any emigration is permanent (Lebreton et al., 1992; Lindenmayer, Lacy, \& Viggers, 1998). This model only includes two parameters: survival probability $(\Phi)$ and capture probability $(\mathrm{p})$, whereas the original Jolly-Seber model allowed for the estimation of apparent survival rates, capture rates, population sizes, and the number of new animals (Pollock, 1982), consequently the CJS model provides greater accuracy in the estimations (Lindenmayer et al., 1998). The survival probability and the capture probability can vary or remain constant over time. The candidate models were: (1) constant $\Phi$ and $\mathrm{p},[\Phi \mathrm{p}]$; (2) constant $\Phi$ and p varying through time (expressed in year: 2011, 2012, and 2013), $\left[\Phi \mathrm{p}_{\mathrm{t}}\right]$; (3) $\Phi$ varying over time and constant $\mathrm{p},\left[\Phi_{\mathrm{t}} \mathrm{p}\right]$; and (4) both $\Phi$ and $\mathrm{p}$ vary over time, $\left[\Phi_{t} p_{t}\right]$ (Lebreton et al., 1992). The best model was selected using the Quasi-Akaike Information Criterion (QAIC; Burnham \& Anderson, 2002). Model parameters were adjusted to minimize overdispersion due to extrabinomial variation, by dividing the observed value of c-hat from the original data by the mean of the simulated values of c-hat from 1000 pseudosamples generated through the bootstrap parametric method (Santos-Moreno, Briones-Salas, \& López-Wilchis, 2007). The program Mark 6.0 was used to run model construction and analysis (Cooch \& White, 2012). Once the final model was selected, population size $(\mathrm{N})$ was calculated as the number of observed individuals divided by the capture probability (Lindenmayer et al., 1998).

In order to estimate the effective sampling area, we calculated the minimum convex polygon area defined by all trapping stations plus a buffer size. As there is still debate about the calculation of buffer size for an effective sampling area (Maffei et al., 2005; Trolle \& Kéry, 2005; Dillon \& Kelly, 2008; Maffei \& Noss, 2008), we used both the mean maximum distance moved by ocelots caught on two or more occasions (MMDM), and half the MMDM $(1 / 2 \mathrm{MMDM})$. The variance of area was estimated follow Karanth and Nichols (1998). Density was calculated as the estimated number of 
individuals by the CJS capture-recapture model divided by the effective sampling area, and extrapolated to a $100 \mathrm{~km}^{2}$ area.

Due to the close distance between the traps, it was important to evaluate whether the observed camera trap captures at one site was independent on the neighboring sites. So, we used Moran Index (I) to evaluate spatial autocorrelation (Sokal \& Oden, 1978) in the camera trap captures. Under the null hypothesis of no spatial autocorrelation, Moran's I has the expected value approaching zero in absence of autocorrelation, with positive and negative values indicating positive and negative autocorrelation, respectively. The tests were using ArcGis 9.3 (Esri, 2008); the inverse distance was used for the computations.

In order to describe activity patterns, all photographs taken by each sampling station within a $1 \mathrm{~h}$ span were considered as a single record (Di Bitetti et al., 2006). The 24h were grouped into one-hour periods, and each photographic record was classified within those intervals. The diurnal activity lasted from 6:00am-20:00, and the nocturnal from 20:0006:00. Circular techniques (Zar, 1999) were used to analyze whether nocturnal and diurnal activity varied significantly through the seasons. We first tested if activity differed from day and night for each season per year. The activity between dry and wet seasons was then compared. The Mardia-Watson-Wheeler test was used to test if activity varied between seasons, and the Watson $\mathrm{U}^{2}$ test was applied if the observations were less than 10. Statistical tests were performed with the software Oriana version 4 (Kovach Computing Services, 2011), and the significance of the test was $\mathrm{p} \leq 0.05$.

To estimate the sex ratio, each identifiable individual was classified into male (testicle presence) and female (without testicle presence). The ratio was expressed as the number of males per female (male:female). A binomial test was performed to determine if the ratios differed significantly from a 1:1 ratio, and the test was significant at $p<0.05$. We counted the period of residence of each individual as the number of months from the first capture to last re-capture.

A Multiple Discriminant Analysis was used to determine which of the selected environmental variables best explains ocelot abundance in the region. The response variable was the number of ocelot records, which were grouped into three record classes: $1=$ zero record; $2=$ from one to four records; and $3=$ more than five. The predictor variables were the following: distance from water bodies (DWB); distance from nearest village (DNV); distance to cornfields and livestock (DCP); altitude (ALT); number of prey records (PR) for each camera trap location; and, habitat (HAB). The habitat was classified as $1=$ livestock; $2=$ trail; $3=$ =rivers; and $4=$ inside the forest. Distances were measured in kilometers, and altitude in meters. Prey species considered had a weight of $\leq 10 \mathrm{~kg}$. All values were standardized by dividing each value by the respective variable's maximum. Spatial data from variables was calculated using ArcGis 9.3 (Esri, 2008; Inegi, 2000), and statistical analyses with Statistica 7 (Statsoft, 2005), and NCSS 2007 (Hintze, 2010).

\section{RESULTS}

The total sampling effort was 8529 trapdays; 543 pictures were of the order Carnivora, of which 128 were ocelots, representing 103 individual records. From the 103 ocelot photographs, 33 could not be identified to an individual level because of poor photograph quality, lighting or position of the animal. From the remaining 70, 34 were right-side pictures, enabling the identification of nine individuals (Table 1); 36 left-side pictures were obtained, with five identified individuals. Two individuals were identified from both sides. Thus, the capture-recapture history matrix was built with right-side picture data, but adding the data of identified individual for both sides, so that the number of records was 57.

The ocelot population was not closed $\left(\chi^{2}=223.47\right.$, d.f. $\left.=20, p=0.000\right)$. There were no additions $(p=0.99)$, however there were population losses $(\mathrm{p}=0.00)$. As for the CJS model 
TABLE 1

Capture-recapture history, sex, and residence time of the nine ocelots in Los Chimalapas, Mexico

\begin{tabular}{cccc} 
Individual & Sex & Residence Time & Capture-recapture history \\
H1 & Female & 12 & 0000000010000000110100000 \\
H2 & Female & 10 & 0000010000001010000000000 \\
H3 & Female & 1 & 1000000000000000000000000 \\
M1 & Male & 23 & 0101100011111111111101110 \\
M2 & Male & 16 & 0000001000000111100001000 \\
M3 & Male & 1 & 0000100000000000000000000 \\
M4 & Male & 1 & 0000100000000000000000000 \\
M5 & Male & 1 & 0010000000000000000000000 \\
NC1 & NC & 1 & 0000000000000000000100000 \\
\hline
\end{tabular}

The presence was established monthly and, each month was considered a sampling occasion. $0=$ no capture, $1=$ capture, $\mathrm{NC}=$ no cataloged.

TABLE 2

Values for CJS capture-recapture model generated by ocelot population estimates in Los Chimalapas, Mexico

\begin{tabular}{cccccc} 
Model & QAICc & Delta QAICc & QAICc weight & Number of Parameters & Qdeviance \\
$\mathrm{p} \Phi_{\mathrm{t}}$ & 120.71 & 0 & 0.75 & 4 & 111.37 \\
$\mathrm{p}_{\mathrm{t}} \Phi_{\mathrm{t}}$ & 123.81 & 3.10 & 0.16 & 6 & 108.81 \\
$\mathrm{p} \Phi$ & 125.34 & 4.63 & 0.07 & 2 & 120.96 \\
$\mathrm{p}_{\mathrm{t}} \Phi$ & 128.41 & 7.70 & 0.07 & 4 & 119.08 \\
\hline
\end{tabular}

$\mathrm{p}=$ capture probability; $\Phi=$ survival probability; QAICc=Quasi-Akaike Information Criterion; Delta QAICc=AICc difference between respective model and best model; QAICc weight=relative contribution of each model regarding the sum of models; Qdeviance $=$ degree of discrepancy between model and data. c-hat $=0.883$.

assumptions, neither the presence of transiting individuals $(\mathrm{p}=0.24)$ nor the camera trap effects in mark and capture history $(\mathrm{p}=0.30)$ were significant. Camera-trap captures were spatially independent in total captures (Moran' $\mathrm{I}=-0.024, \mathrm{p}=0.97$ ), captures in 2011 $(\mathrm{I}=-0.015, \mathrm{p}=0.95), 2012 \quad(\mathrm{I}=0.062, \mathrm{p}=0.75)$, and $2013(\mathrm{I}=-0.475, \mathrm{p}=0.23)$.

After adjusting parameters with the overdispersion correction factor (c-hat $=0.88$ ), the best model was $\left[\Phi_{\mathrm{t}}, \mathrm{p}\right]$, supported by $75 \%$ of the data. The second best model was $\left[\Phi_{t}, p_{t}\right]$, supported by $16 \%$ of the data (Table 2). According to the best model, estimate abundance was 20.13(SE=0.08). There were five individuals in two or more trap locations, with an average maximum distance traveled of $2.6 \mathrm{~km}$, so density was 38 individuals $/ 100 \mathrm{~km}^{2}(95 \%$ Confidence Interval=29-56) with $1 / 2 \mathrm{MMDM}$, and 22 individuals $/ 100 \mathrm{~km}^{2}$ (95\% Confidence Interval=17-32) with MMDM (Table 3).

We obtained 104 independent records from which to describe activity patterns. The ocelot was more active at night, but it also showed diurnal activity throughout the study period. Maximum activity occurred between 1:00-6:00 (Fig. 1). The differences between nocturnal and diurnal activity in each period were significant $(p<0.05)$ and so a separate analysis was carried out. Because within each season (dry or wet) the differences between years $(2011,2012$ and 2013) for nocturnal ( $U^{2}$ of the Watson test ${ }_{\text {wet }}$ season $=0.051, \mathrm{p}>0.5 ; \mathrm{U}^{2}$ dry season $\left.=0.138, \mathrm{p}>0.1\right)$ or diurnal activity $\left(\mathrm{U}^{2}\right.$ wet season $=0.057, \mathrm{p}>0.5$; $\mathrm{U}^{2}$ dry season $=0.029, \mathrm{p}>0.5$ ) were not significant, the data between years was pooled as a single sample in final analysis. The differences in nocturnal activity between the wet and dry 
TABLE 3

Abundance and ocelot density (individuals per $100 \mathrm{~km}^{2}$ ) obtained by CJS model, including parameters related to its calculation

\begin{tabular}{cccccc} 
Abundance (SE) & Density(CI) & Total area & Buffer(SE) & p(SE) & $\varphi(\mathrm{SE})$ \\
$20.13(0.08)$ & $38(29-56)$ & $52 \mathrm{~km}^{2}$ & $1 / 2 \mathrm{MMDM}=1.3 \mathrm{~km}(0.8)$ & $0.44(0.07)$ & $\Phi_{2011} 0.65(0.14)$ \\
& $22.6(17-32)$ & $89 \mathrm{Km}^{2}$ & $\mathrm{MMDM}=2.6 \mathrm{~km}(0.8)$ & & $\Phi_{2012} 0.99(0.02)$ \\
& & & & $\Phi_{2013} 0.78(0.16)$ \\
\hline
\end{tabular}

Best CJS model was $\mathrm{p} \Phi_{\mathrm{t}} ; \mathrm{n}=9$ individuals; $\mathrm{p}=$ capture probability; $\Phi_{1}$ to $\Phi_{3}=$ survival probability during each of the three years. $\mathrm{CI}=95 \%$ Confidence Interval.
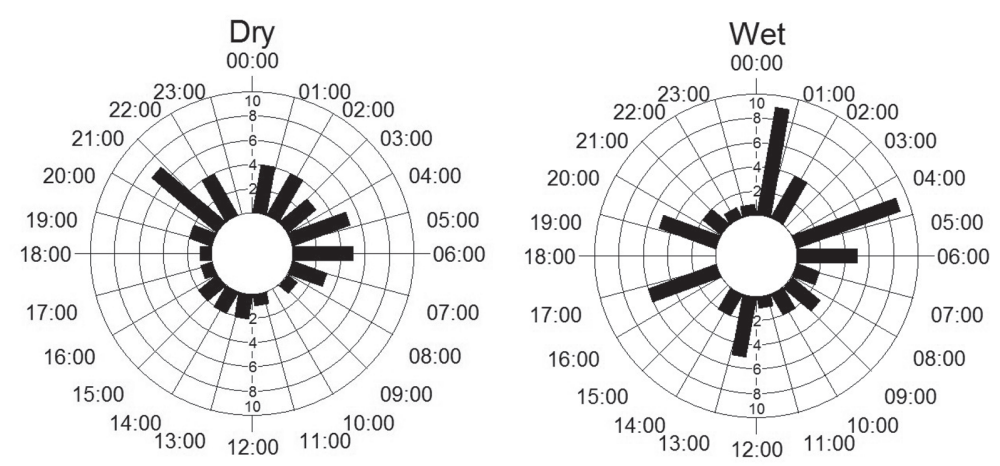

Fig. 1. Ocelot activity patterns for the wet and dry seasons in Los Chimalapas, SE Mexico.

seasons were not significant (W of the MardiaWatson-Wheeler test $=1.047, \mathrm{p}=0.59$ ) and the differences in diurnal activity between the two periods were not significant $(\mathrm{W}=0.37, \mathrm{p}=0.83$ ).

Three females and five males were recorded, and one individual was not classified. The sex ratio was $1: 0.6$, but it was not significantly different from 1:1 ( $\mathrm{z}=0.35, \mathrm{p}=0.72)$. Regarding presence, five of nine ocelots $(55 \%)$ were observed during a single month, one for 10 months, one for 12 , one for 16 , and one for 23 (mean $=7.33,95 \%$ confidence interval from four to 10 months) (Table 1).

Discriminant Function 1 explained $71 \%$ of total variance. The most important variable was the proximity to the village and, for the Discriminant Function 2, the number of prey records. Both functions show a tendency for trap grouping in function of ocelot abundance classes, particularly in discriminating the sites without ocelot records (Fig. 2). Stations with the highest number of ocelot records showed a high number of prey records (mean=58.3) and were $3-6 \mathrm{~km}$ from the village. In contrast, stations without ocelot records showed a low value of prey records (mean=3.4) and were $5-8 \mathrm{~km}$ from the village (Table 4 ).

\section{DISCUSSION}

The estimated ocelot population density in Los Chimalapas was 38 individuals $/ 100 \mathrm{~km}^{2}$. This density was within the range of 6 to 106 individuals $/ 100 \mathrm{~km}^{2}$, observed in the tropical deciduous forest, tropical oaks forest or subtropical thornscrub in the North and Center of Mexico (López-González et al., 2003; Martínez, 1997). In other rainforests in Southeast Mexico, the density was 14 individuals $/ 100 \mathrm{~km}^{2}$ (Torres, 2009), so, the density in Los Chimalapas was higher. In other eco-regions such as Los Llanos in Venezuela, the Pantanal in Brazil or the dry forest in Bolivia, the calculated density was from 11 to 59 individuals $/ 100 \mathrm{~km}^{2}$ (Ludlow \& Sunquist, 1987; Maffei et al., 2005; 


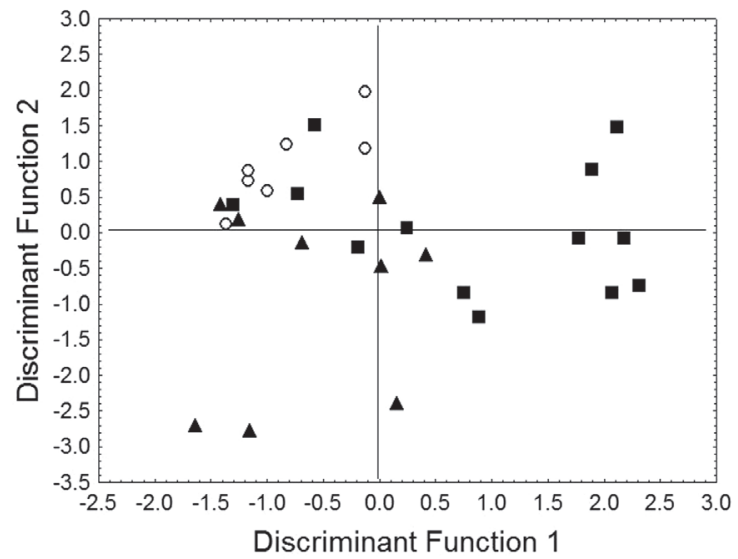

Fig. 2. Dispersion graph for ocelot abundance class over the two discriminant functions. The variable for Discriminant Function 1 was the nearness to the village, and for Discriminant Function 2 was the prey record. Circles $=0$ records; square $=1$ to 4 records; triangles $=$ more than 5 ocelot records.

TABLE 4

Discriminating Function (DF) values, standardized canonical coefficients, and the means of the original variables

\begin{tabular}{|c|c|c|c|c|c|c|}
\hline \multirow[b]{2}{*}{ Variable } & \multirow[b]{2}{*}{ Group 1} & \multicolumn{2}{|l|}{ Means } & \multirow[t]{2}{*}{ Total range } & \multicolumn{2}{|c|}{$\begin{array}{c}\text { Standardized Canonical } \\
\text { Coefficients }\end{array}$} \\
\hline & & Group 2 & Group 3 & & FD 1 & FD 2 \\
\hline HAB & $4^{*}$ & 1 and $4 *$ & 2 and $4 *$ & & -0.515 & 0.229 \\
\hline DWB & $0.63(0.4)$ & $1.44(1.1)$ & $0.53(0.4)$ & $0.09-3.03$ & 0.329 & -0.108 \\
\hline DNV & $6.69(1.0)$ & $4.01(2.3)$ & $4.88(1.5)$ & $0.37-8.19$ & -0.681 & -0.505 \\
\hline DCP & $1.86(1.1)$ & $1.36(0.8)$ & $1.08(0.6)$ & $0.24-3.13$ & 0.462 & -0.281 \\
\hline ALT & $330(120)$ & $396(147)$ & $332(132)$ & $138-674$ & 0.509 & -0.600 \\
\hline PR & $3.43(3.9)$ & $25(29)$ & $58.3(86.9)$ & $0-254$ & -0.033 & 1.007 \\
\hline \multirow[t]{2}{*}{ Ocelot records } & 0 & $1.46(0.78), \mathrm{n}=19$ & $9.33(6.76), n=85$ & & & \\
\hline & Eigenvalue & $\begin{array}{c}\% \text { of total } \\
\text { explained variance }\end{array}$ & Canonical Correlation & & & \\
\hline FD1 & 0.716 & 61.5 & 0.64 & & & \\
\hline FD2 & 0.449 & 100 & 0.55 & & & \\
\hline
\end{tabular}

Variable value (Standard Deviation). Abundance class: Group 1=0 records, group 2=1-4 records, group $3=5$ or more records. $\mathrm{HAB}=$ habitat; $\mathrm{DWB}=$ distance from water bodies, $\mathrm{DNV}=$ distance from nearest village, $\mathrm{DCP}=$ distance to cornfields and livestock areas; $\mathrm{ALT}=$ altitude; $\mathrm{PR}=$ medium sized preys records. *the location traps was in $1=$ livestock, $2=$ trail, $3=$ river, and $4=$ inside the forest. Distances were measured in kilometers and altitude in meters.

Trolle \& Kéry, 2003; 2005; Díaz-Pulido \& Payan, 2011), and in other similar rainforests in the Americas, densities were from 8 to 75individuals $/ 100 \mathrm{~km}^{2}$ (Di Bitetti et al., 2006; 2008a; Kolowski \& Alonso, 2010; GonzálezMaya \& Cardenal-Porras, 2011). Therefore, the population density observed in Los Chimalapas is neither high nor low in comparison with these regions.
The capture-recapture models for closed populations are widely used in the estimation of ocelot population size, but until now, the open population models had not been used for this species. Open population models are the most appropriate choice when studies are carried out over a longer time period, when populations show additions and/or losses, such as the ocelot population in Los Chimalapas, 
something which is not considered in closed population models (Lebreton et al., 1992). Despite the distance of the traps, captures were spatially independent and model assumption was not violated. The CJS model can produce biases in the parameter estimation due to the violation of the other assumptions (equal probabilities of capture and survival, and the permanence and migration) because there were variations between individuals in terms of age, sex, or migration of the ocelot (Laak, 1991; Caso, 1994). Open population models allow us to observe variations in certain parameters over time (Gutiérrez-González et al., 2012). Thus, this model is a suitable tool for the study of populations that require long-term monitoring, and it is useful for the implementation of effective strategies for carnivore conservation in the region.

It has been observed in previous studies that the ocelot density is high in ecoregions near the Equator and with high rainfall. The generated model indicates that ocelot densities decrease with latitude and increase with rainfall (Di Bitetti et al., 2008a). The CJS model estimation was consistent with patterns of abundance according to this model: 37 to 56 individuals $/ 100 \mathrm{~km}^{2}$ using the model of latitude and precipitation, respectively. So, the geographic location of Los Chimalapas may be a determining factor in ocelot density. Los Chimalapas is considered a well-preserved region: about $90 \%$ of the forest is conserved and the presence of human activity and the proportion of livestock areas are low (Ortega del Valle, Carranza, \& Martínez, 2012). The ocelot density tends to be higher in better preserved areas than in those exposed to human activity: 20-56 compared with 11 individuals $/ 100 \mathrm{~km}^{2}$, respectively (Trolle \& Kéry, 2003; Di Bitetti et al., 2006).

The region has a significant variety of potential prey species, but there is no data on ocelot diet in the area. However, studies in rainforests in Central and South America indicate that small mammals are most common in the ocelot diet, but that the Central American agouti Dasyprocta punctata (Saussure, 1860) and the paca Cuniculus paca (Linnaeus, 1776) are also important in terms of biomass and frequency (Moreno, Kays, \& Samudio, 2006; de Oliveira et al., 2010). These species are present in Los Chimalapas with high relative abundances: about $19 \%$ of total records were for these two species (G. Pérez, in prep.). In surrounding areas, the C. paca population was high, in comparison to other area: $67-70$ individuals $/ 100 \mathrm{~km}^{2}$ (Parroquin, Gallina, Aguirre, \& Pérez, 2010; Santos-Moreno \& Pérez-Irineo, 2013). This prey species constitute a food base able to sustain predator populations, such as the ocelot. In other habitats, the density of predators like the tiger Panthera tigris (Linnaeus, 1758; Karanth, Nichols, Kumar, Link, \& Hines, 2004), the jaguar (Polisar et al., 2003), and others (Carbone, Pettorelli, \& Stephens, 2011) was positively correlated with prey density.

Sex ratio in the ocelot population of Los Chimalapas was 1:1. In contrast, in South American populations, the number of females was greater than that of males (Ludlow \& Sunquist, 1987; Di Bitetti et al., 2006). The males move more widely, for the search of an available home range, the defense of territory, or for the reproduction, so that they were recorded more frequently (Laak, 1991; Caso, 1994). While no offspring or young were found during the study period, one of the identified females was pregnant during the dry season of 2011, suggesting that the ocelot population was reproductive.

The population seems to include an important percentage of transient individuals; $50 \%$ of identified individuals were observed in the area only during a single month, and only two individuals remained in the area for more than 16 months. Based on other wide studies ( $>2.5$ years), young ocelots disperse and establish a home range after the 14-35 months of age (Laak, 1991; Haines et al., 2005; Mares, Moreno, Kays, \& Wikelski, 2008). Due to the duration of this study (27 month), there is some uncertainty as to the classification of these two individuals as residents, however it also provides insight into this parameter in the ocelot population in the area. The transient individuals 
could have migrated to other areas, such as Sierra Tres Picos, in Central Los Chimalapas or as the Uxpanapa region in Veracruz. Both regions are important flora and fauna preservation areas (Salas et al., 2001).

In Los Chimalapas, the ocelot showed primarily nocturnal activity. However, the diurnal activity was present throughout the study period. In several studies, the ocelot activity was primarily nocturnal (18:00-6:00), with little diurnal activity (Ludlow \& Sunquist, 1987; Emmons, 1988; Maffei et al., 2005; Di Bitetti et al., 2006). In other studies, $38 \%$ of the activity was diurnal (Caso, 1994). The amplitude of the activity pattern recorded in Los Chimalapas may result from two factors: the availability of prey both day and night, and low human activity and poaching in the area.

Although the paca's activity pattern is variable throughout its distribution, in San Antonio Nuevo Paraíso the species was nocturnal (Gregorio, 2012); whereas the agouties were diurnals (G. Pérez, in prep.). The relationship between mesopredator activity and prey has been observed in other studies (Ludlow \& Sunquist, 1987), as well as for other predator species such as the puma, the jaguar and the tiger (Paviolo, Di Blanco, De Angelo, \& Di Bitetti, 2009; Harmsen, Foster, Silver, Ostro, \& Doncaster, 2011).

On the other hand, human presence was scarce in the area and poaching was only for local consumption, therefore, the ocelot was active without the risk of being hunted and their activity was wider than in other regions. In the Yucatan Peninsula, Mexico, the ocelot activity was nocturnal (Torres, 2009). In this region, the climatic conditions are similar to Los Chimalapas, but with a long history of disturbance. In regions where the ocelot is hunted, its activity is completely nocturnal (Sunquist \& Sunquist, 2002). It can thus be established that the quality of the region and the presence of prey determine activity rather than the physical conditions. In other species, the activity amplitude was also less in areas with human activity. Pumas show activity during both periods of the day in areas or seasons with low poaching; on the other hand, they were mainly nocturnal in areas with high poaching (Paviolo et al., 2009). In canids, the activity shifts as a strategy to avoid human contact (Kitchen, Gese, \& Schauster, 2000). This same pattern was observed in cat's larger prey in other regions (Di Bitetti, Paviolo, Ferrari, De Angelo, \& Di Blanco, 2008b).

In this study, the proximity to the water supply and livestock areas does not seem to affect the ocelot presence, probably due to the abundance of water in the region. Perhaps on a larger scale this effect would be different, as with other felids (Hatten, Averril-Murray, \& Van Pelt, 2003; Monroy-Vilchis, RodríguezSoto, Zarco-González, \& Urios, 2009). In contrast, ocelot spatial distribution was positively affected by the proximity to the village and the greater amount of prey. No vehicular traffic exists in the region, and pressure of human activities is considered low. So, the ocelot occupies different areas without the risk of vehicular collision or poaching.

In Los Chimalapas, potentially useable areas for livestock were used by the ocelot, such as areas near the village. These areas have dense vegetation cover, but if vegetation cover is reduced, the ocelot would avoid them. The ocelot supports some degree of disturbance, but they are dependent on dense cover (Sunquist \& Sunquist, 2002; Harveson et al., 2004; de Oliveira et al., 2010). An increase in open areas would negatively affect the ocelot movement and dispersion routes (Haines et al., 2005; Harveson et al., 2004; Grigione et al., 2009) and consequently the ocelot distribution pattern. This species occupies a wide range of microhabitats and uses trails and roads, indicating a wide ecological plasticity (Murray \& Gardner, 1997; Sunquist \& Sunquist, 2002).

The ocelot is listed as an endangered species by Mexican law (Semarnat, 2010); it is among the ten species with the highest conservation priority in the country (Valenzuela \& Vázquez, 2007). In Los Chimalapas, the ocelot population enjoys ecological and environmental conditions that favor its presence in the mid and long term. However, changes in 
vegetation cover will affect the ocelot population, activity and, distribution in the long-term. Thus, it is important to continue long-term ecological studies on different species and their possible population shifts with appropriate analytical tools.

\section{ACKNOWLEDGMENTS}

The authors thank the San Antonio Nuevo Paraíso community in Mexico for the facilities granted; IDEAWILD for the donated materials; the Laboratorio de Análisis Geoespacial, CIIDIR-IPN Unidad Oaxaca for support on geographical information; CONACyT for a scholarship provided to the first author; and IPN for funding (Projects SIP-20110395, SIP20120962, and SIP-20131154 to A. SantosMoreno). We thank R. del Castillo, M. Garcia, G. Ramos, R. Solano, and the three anonymous reviewers for their suggestions on the realization of the manuscript.

\section{RESUMEN}

Densidad, distribución y actividad del ocelote Leopardus pardalis (Carnivora: Felidae) en los bosques húmedos del sureste mexicano. El ocelote Leopardus pardalis es importante en comunidades terrestres debido a su papel ecológico dentro del grupo de felinos de tallas pequeñas y como mesodepredador. A pesar de la disminución del hábitat del ocelote en el sureste de México, son pocos los estudios ecológicos. El siguiente trabajo presenta una contribución de algunos aspectos ecológicos de la especie en esta región. Se estimó la densidad poblacional, patrón de actividad, proporción de sexos, tiempo de residencia y distribución espacial del ocelote. El estudio se llevó a cabo mediante fototrampeo dentro de Los Chimalapas, en el estado de Oaxaca, sureste de México. Se establecieron 29 estaciones dentro de la selva alta y se cubrió un área de $22 \mathrm{~km}^{2}$, durante dos años (marzo 2011-junio 2013). La densidad fue estimada usando Modelos de Captura-Recaptura para poblaciones demográficamente abiertas, las técnicas circulares fueron usadas para determinar si la actividad nocturna y diurna varió significativamente entre épocas y, un análisis discriminante múltiple fue usado para conocer cuáles variables explican mejor la abundancia del ocelote en la región. Se obtuvieron 103 registros de ocelote con un esfuerzo de 8529 días-trampa. Se estimó una densidad de 22-38 individuos $/ 100 \mathrm{~km}^{2}$. La población del ocelote tuvo un porcentaje alto de transeúntes $(55 \%)$ y la proporción de sexos fue estadísticamente similar de 1:1. El ocelote estuvo más activo en la noche (1:00-6:00am), pero exhibió actividad diurna durante todo el periodo de estudio. La distribución espacial estuvo afectada positivamente por la proximidad a poblados y por la cantidad de presas. La población del ocelote parece estable, con una densidad similar a otras regiones de Centro y Sudamérica, quizá debido a la diversidad de especies presa y al grado bajo de alteración en Los Chimalapas.

Palabras clave: captura-recaptura, fototrampeo, Los Chimalapas, Modelo CJS.

\section{REFERENCES}

Burnham, K. P. \& Anderson, D. R. (2002). Model Selection and Inference -A Practical Information- Theoretic Approach. Nueva York: Springer-Verlag.

Carbone, C., Pettorelli, N., \& Stephens, P. A. (2011). The bigger they come, the harder they fall: body size and prey abundance influence predator-prey ratios. Biology Letters, 7, 312-315.

Caso, A. (1994). Home range and habitat use of three neotropical carnivores in Northeast Mexico. (Master's thesis). Texas University, Kingville.

Ceballos, G., Chávez, C., List, R., \& Zarza, H. (2007). Conservación y manejo del jaguar en México. Estudios de caso y perspectivas. Ciudad de México: Alianza WWF/Telcel, Comisión Nacional para el Conocimiento y Uso de la Biodiversidad, UNAM, Comisión Nacional de Áreas Naturales Protegidas \& EcoCiencia S.C.

Choquet, R., Lebreton, J. D., Gimenez, O., Reboulet, A. M., \& Pradel, R. (2009). U-CARE: Utilities for performing goodness of fit tests and manipulating Capture-Recapture data. Ecography, 32, 1071-1074.

Cooch, E. \& White, G. (2012). Program Mark. Analysis of data from marked individuals. A gentle introduction. Nueva York: Connell University.

de Oliveira, T. G., Tortato, M. A., Silveira, L., Kasper, C. B., Mazim, F. D., Lucherini, M., ... \& Sunquist, M. (2010). Ocelot ecology and its effect on the small-felid guild in the lowland neotropics. In D. W. Macdonald \& A. J. Loveridge (Eds.), Biology and conservation of wild felids (pp. 559-596). Nueva York: Oxford University Press.

Di Bitetti, M. S., Paviolo, A., \& De Angelo, C. (2006). Density, habitat use and activity patterns of ocelots (Leopardus pardalis) in the Atlantic Forest of Misiones, Argentina. Journal of Zoology, 270, 153-163.

Di Bitetti, M. S., Paviolo, A., De Angelo, C. D., \& Di Blanco, Y. E. (2008a). Local and continental correlates of the abundance of a Neotropical cat, the ocelot (Leopardus pardalis). Journal of Tropical Ecology, 24, 189-200.

Di Bitetti, M. S., Paviolo, A., Ferrari, C. A., De Angelo, C. D., \& Di Blanco, Y. E. (2008b). Differential responses to hunting in two sympatric species of brocket 
deer (Mazama americana and M. nana). Biotropica, 40, 636-645.

Díaz-Pulido, A. \& Payan, E. (2011). Densidad de ocelotes (Leopardus pardalis) en Los Llanos Colombianos. Mastozoología Neotropical, 18, 63-71.

Dillon, A. \& Kelly, M. J. (2008). Ocelot home range, overlap and density: comparing radio telemetry with camera trapping. Journal of Zoology, 275, 391-398.

Emmons, L. H. (1988). A field study of ocelot (Felis pardalis) in Peru. Review d'Ecologie, 43, 133-157.

Esri. (2008). ArcGis version 9.3. http://www.esri.com/ software/arcgis

González-Maya, J. F. \& Cardenal-Porras, J. (2011). Ocelot density in the Caribbean slope of the Talamanca region, Costa Rica. Hystrix, the Italian Journal of Mammalogy, 22, 355-360.

Gregorio, L. C. (2012). Estimación de algunos parámetros demográficos poblacionales de tepezcuintle (Cuniculus paca) en San Antonio Nuevo Paraíso, Santa Maria Chimalapa, Oaxaca. Informe técnico de Residencia Profesional. Oaxaca: Instituto tecnológico del Valle de Oaxaca.

Grigione, M. M., Menke, K., López-González, C., List, R., Banda, A., Carrerea, J., ... \& Van Pelt, B. (2009). Identifying potential conservation areas for felids in the USA and Mexico: integrating reliable knowledge across an international border. Oryx, 43, 78-86.

Gutiérrez-González, C. E., Gómez-Ramírez, M. A., \& López-González, C. A. (2012). Estimation of the density of the near threatened jaguar Panther onca in Sonora, Mexico, using camera trapping and an open population model. Oryx, 46, 431-437.

Haines, A. M., Tewes, M. E., Laack, L. L., Grant, W. E., \& Young, J. (2005). Evaluating recovery strategies for an ocelot (Leopardus pardalis) population in the United States. Biological Conservation, 126, 512-522.

Harmsen, B. J., Foster, R. J., Silver, S. C., Ostro, L. E. T., \& Doncaster, C. P. (2011). Jaguar and puma activity patterns in relation to their main prey. Mammalian Biology, 76, 320-324.

Harveson, P. M., Tewes, M. E., Anderson, G. L., \& Laak, L. L. (2004). Habitat use by ocelots in south Texas: implications for restoration. Wildlife Society Bulletin, 32, 948-954.

Hatten, J. R., Averril-Murray, A., \& Van Pelt, W. E. (2003). Characterizing and mapping potential jaguar habitat in Arizona. Nongame and Endangered Wildlife Program, Technical Report 203. Arizona: Game and fish Department.

Hintze, J. (2010). NCSS Statistical data analysis software. http://www.ncss.com

Inegi. (2000). Red hidrológica escala 1:50 000 y modelo digital de elevación 1:50 000. http://www.inegi.org. $\mathrm{mx}$
Karanth, K. U. \& Nichols, J. D. (1998). Estimation of tiger densities in India using photographic captures and recaptures. Ecology, 79, 2852-2862.

Karanth, K. U., Nichols, J. D., Kumar, N. S., Link, W. A., \& Hines, J. E. (2004). Tigers and their prey: predicting carnivore densities from prey abundance. Proceedings of the National Academy of Sciences of the United States of America, 101, 4854-4858.

Kitchen, A. M., Gese, E. M., \& Schauster, E. R. (2000). Changes in coyote activity patterns due to reduced exposure to human persecution. Canadian Journal of Zoology, 78, 853-857.

Kolowski, J. M. \& Alonso. A. (2010). Density and activity patterns of ocelots (Leopardus pardalis) in northern Peru and the impact of oil exploration activities. Biological Conservation, 143, 917-925.

Kovach Computing Services. (2011). Software Oriana version 4. http://www.kovcomp.co.uk/oriana/oribroc. $\mathrm{html}$

Laak, L. L. (1991). Ecology of the ocelot (Felis pardalis) in south Texas. (Master's thesis). Texas University, Kingsville.

Lebreton, J. D., Burnham, K. P., Clobert, J., \& Anderson, D. R. (1992). Modeling survival and testing biological hypotheses using marked animal: A unified approach with case studies. Ecological Monographs, $62,67-118$.

Lindenmayer, D. B., Lacy, R. C., \& Viggers, K. L. (1998). Modeling survival and capture probabilities of the mountain brushtail possum (Trichosurus caninus) in the forests of southeastern Australia using traprecapture data. Journal of Zoology, 245, 1-13.

Lira-Torres, I., Galindo-Leal, C., \& Briones-Salas, M. (2012). Mamíferos de la Selva Zoque, México: riqueza, uso y conservación. Revista de Biología Tropical, 60, 781-797.

López-González, C. A., Brown, D. E., \& Gallo-Reynoso, J. P. (2003). The ocelot Leopardus pardalis in northwestern Mexico: ecology, distribution and conservation status. Oryx, 37, 358-364.

Ludlow, M. E. \& Sunquist, M. E. (1987). Ecology and behavior of ocelots in Venezuela. National Geographic Research, 3, 447-461.

Maffei, L., Noss, A. J., Cuéllar, E., \& Rumiz, D. I. (2005). Ocelot (Felis pardalis) population densities, activity, and ranging behaviour in dry forest of Eastern Bolivia: data from camera trapping. Journal of Tropical Ecology, 21, 1-6.

Maffei, L. \& Noss, A. J. (2008). How small is too small? Camera trap survey areas and density estimates for ocelots in the Bolivian Chaco. Biotropica, 40, 71-75.

Mares, R., Moreno, R. S., Kays, R. W., \& Wikelski, M. (2008). Predispersal home range shift of an ocelot Leopardus pardalis (Carnivora: Felidae) on Barro 
Colorado Island, Panama. Revista de Biología Tropical, 56, 779-787.

Martínez, E. (1997). Estudio ecológico del ocelote (Leopardus pardalis) en la zona de Chamela, Jalisco, México. (Tesis de Maestría). UNAM, México D. F.

Martínez-Calderas, J. M., Rosas-Rosas, O. C., MartínezMontoya. J. F., Tarango-Arámbula, L. A., ClementeSánchez, F., Crosby-Galván, M. M., \& Sánchez Hermosillo, M. D. (2011). Distribución del ocelote (Leopardus pardalis) en San Luis Potosí, México. Revista Mexicana de Biodiversidad, 82, 997-1004.

Monroy-Vilchis, O., Rodríguez-Soto, C., Zarco-González, M., \& Urios, V. (2009). Cougar and jaguar habitat use and activity patterns in central Mexico. Animal Biology, 59, 145-157.

Monroy-Vilchis, O., Zarco-González, M. M., RodríguezSoto, C., Soria-Díaz, L., \& Urios V. (2011). Fototrampeo de mamíferos en la Sierra Nanchititla, México: abundancia relativa y patrón de actividad. Revista de Biología Tropical, 59, 373-383.

Moreno, R. S., Kays, R. W., \& Samudio, R. (2006). Competitive release in diets of ocelot (Leopardus pardalis) and puma (Puma concolor) after jaguar (Panthera onca) decline. Journal of Mammalogy, 87, 808-816.

Murray, J. L. \& Gardner, G. L. (1997). Leopardus pardalis. Mammalian Species, 548, 1-10.

Ortega del Valle, D., Carranza, T., \& Martínez, J. (2012). Una mirada desde el corazón de la jícara de oro. Experiencias de conservación en la Selva Zoque de Los Chimalapas. Oaxaca: WWF-México.

Parroquin, J., Gallina, S., Aguirre, G., \& Pérez, J. (2010). El tepezcuintle: estrategias para su aprovechamiento con base en la evaluación de su población y hábitat en el ejido Loma de Oro, Uxpanapa, Veracruz, México. In M. M. Guerra Roa, S. Calmé, S. Gallina, \& E. J. Naranjo (Eds.), Uso y manejo de fauna Silvestre en el norte de Mesoamérica (pp. 137-160). Xalapa: Secretaria de Educación de Veracruz.

Paviolo, A., Di Blanco, Y. E., De Angelo, C. D., \& Di Bitetti, M. (2009). Protection affects the abundance and activity patterns of pumas in the Atlantic Forest. Journal of Mammalogy, 90, 926-934.

Polisar, J., Maxit, I., Scognamillo, D., Farrell, L., Sunquist, M. E., \& Eisenberg, J. (2003). Jaguar, pumas, their prey base, and cattle ranching: ecological interpretation of a management problem. Biological Conservation, 109, 297-310.

Pollock, K. H. (1982). A capture-recapture design robust to unequal probability capture. Journal of Wildlife Management, 46, 752-757.

Reyes, J., Mas, J., \& Velázquez, A. (2010). Trends of tropical deforestation in Southeast Mexico. Singapore Journal of Tropical Geography, 31, 180-196.

Salas, S. H., Schibli, L., \& Torres, E. (2001). La importancia ecológica y biológica. In A. Aparicio Cid (Ed.),
Chimalapas, la última oportunidad (pp. 29-47). Ciudad de México: Word Wildlife Found y Secretaria del medio Ambiente, Recursos Naturales y Pesca.

Santos-Moreno, A., Briones-Salas, M. A., \& López-Wilchis, R. (2007). Diferencias en algunos parámetros demográficos de Oryzomys chapmani (Rodentia: Muridae) asociadas a tres estados sucesionales de bosque mesófilo de montaña en Oaxaca, México. Acta Zoológica Mexicana (n.s.), 23, 123-137.

Santos-Moreno, A. \& Pérez-Irineo, G. (2013). Estimación de abundancia de tepezcuinte (Cuniculus paca) y de su relación con la presencia de competidores y depredadores. Therya, 4, 89-98. Retrieved from http:// www1.inecol.edu.mx/azm/_231_2007.htm

Semarnat. (2010). Norma Oficial Mexicana NOM-059-SEMARNAT-2010, Protección ambiental-Especies nativas de México de flora y fauna silvestres. Categoría de riesgo y especificaciones para su inclusión, exclusión o cambio. Lista de especies en riesgo. México: Diario Oficial de la Federación.

Sokal, R. R. \& Oden, N. L. (1978). Spatial autocorrelation in Biology. 1. Methodology. Biological Journal of the Linnean Society, 10, 199-228.

Stanley, T. R., \& Richards, J. D. (1999). CloseTest. A program for testing capture-recapture data for closure, v. 3. Colorado: US Geological Survey.

Statsoft. (2005). Statistical data analysis software, version 7.1. http://www.statsoft.com

Sunquist, M. \& Sunquist, F. (2002). Wild cats of the world. Chicago: The University of Chicago Press.

Torres, E. J. (2009). Densidad, abundancia, uso de hábitat $y$ patrones de actividad del ocelote (Leopardus pardalis) en la zona noreste del Estado de Quintana Roo: Estudio usando cámaras trampa. (Tesis de Maestría). Colegio de la Frontera Sur, México.

Trejo, I. (2004). Clima. In A. J. García-Mendoza, M. J. Ordoñez \& M. Briones-Salas (Eds.), Biodiversidad de Oaxaca (pp. 67-85). Ciudad de México: Instituto de Biología, UNAM-Fondo Oaxaqueño para la Conservación de la Naturaleza-Word Wildlife Fund.

Trolle, M. \& Kéry, M. (2003). Estimation of ocelot density in the Pantanal using capture-recapture analysis of camera-trapping data. Journal of Mammalogy, 84, 607-614.

Trolle, M. \& Kéry, M. (2005). Camera-trap study of ocelot and other secretive mammals in the northem Pantanal. Mammalia, 69, 405-412.

Valenzuela, D., \& Vázquez, L. B. (2007). Consideraciones para priorizar la conservación de carnívoros mexicanos. In G. Sánchez-Rojas \& A. Rojas-Martínez (Eds.), Tópicos en sistemática, biogeografía, ecología y conservación de mamíferos (pp. 197-214). Hidalgo: Universidad Autónoma del Estado de Hidalgo.

Zar, J. H. (1999). Biostatistical Analysis. Nueva Jersey: Prentice Hall. 